\title{
Algunas expresiones de orgullo local en la Sevilla del Siglo de Oro
}

\author{
Javier Portús Pérez
}

Del interesante * epistolario de Rodrigo Caro forma parte una carta dirigida al erudito aragonés Francisco Andrés de Uztárroz en la que comenta de Pedro Martín de Roa que "era tan aficionado a su Córdoba, que casi le llegaban a pesar de las grandezas de las otras ciudades y de los santos y varones insignes de ellas" '. En realidad, el excesivo interés del cordobés por ponderar las excelencias de su propia ciudad era compartido por la práctica totalidad de los historiadores españoles del Siglo de Oro -incluido el propio Caro-, quienes en muy pocos casos se vieron movidos por el deseo de abordar temas de la historia nacional, y casi siempre hicieron de sus lugares de origen o de residencia los objetos principales de su investigación. La historiografía del momento se define así por su vocación localista, como puede comprobar todo aquel que repase el repertorio de José Simón Díaz sobre bibliografía local española ${ }^{2}$. La causa de esto hay que buscarla en parte en la existencia de una Historia general de España - la de Mariana- de muy alta calidad y que ponía el listón muy alto para todo aquel que quisiera continuarla o rehacerla; pero también hay que tener en cuenta que en la Edad Moderna se desarrolló entre los habitantes de las ciudades un fuerte sentido

- Una parte importante del material iconográfico al que este articulo hace referencia se recoge en CABrA, D., y SANtiago, E., Iconografia de Sevilla. 1400-1650. Madrid 1988; y en Oliver, A., Serreera, J.M., y Portus, J., Iconografia de Sevilla. 1650-1790. Madrid 1989; a los que nos referiremos como lconografía ... I e lconografía ... II, respectivamente. En la realización de este artículo he recibido la gentil ayuda de Lola Gómez de Aranda, que quiero agradecer desde esta nota.

CARO, R., Varones ilustres en letras naturales de la ilustrisima Ciudad de Sevilla. Epistolario, ed. S. Montoto. Sevilla 1915, pág. 111.

${ }^{2}$ Simon Diaz, J., Bibliografia regional y local de España. Madrid 1976. 
de comunidad, en gran parte heredado de la Edad Media, y que encuentra una de sus expresiones más características en la abundancia de grandes celebraciones públicas en las que participaba todo el cuerpo social. Para alimentar este orgullo local se impulsaron extraordinariamente los estudios sobre la historia eclesiástica o política de las poblaciones, que en muchos casos adquirian un carácter polémico, pues estaban orientados a mostrar las excelencias propias en detrimento de la de los vecinos.

Diversas circunstancias -entre las que ocupa un lugar no desdeñable la concesión del monopolio del tráfico con Las Indias - hicieron de la Sevilla de la segunda mitad del siglo XVI y del primer tercio del xVII la ciudad más populosa y con más fecunda vida intelectual, económica y social de España, y una de las poblaciones punteras de Europa. Este hecho no pasó desapercibido entre los españoles; si hemos de juzgar por las obras literarias de la época, en las que se llama frecuentemente la atención sobre él. La conciencia de la prosperidad y riqueza de la ciudad se advierte incluso en formas literarias de difusión popular, como el refranero, que entre sus piezas cuenta con una que reza “A quien Dios quiere bien, en Sevilla le dio de comer" ${ }^{3}$. Por otra parte, la gran cantidad de viajeros extranjeros que recalaron en la ciudad y que a su vuelta a sus lugares de origen propagarian de palabra o por escrito sus excelencias, contribuyó a que el nombre de Sevilla fuera muy estimado por toda Europa ${ }^{4}, y$ de ello nos quedan pruebas expresivas, por ejemplo, en numerosos mapamundis que entre las ciudades que representan en la orla incluyen a la del Guadalquivir, o en los escritorios italianos que ornan sus frentes con representaciones de las grandes urbes europeas, entre las que no suele faltar «Hispalis» 5 .

Los sevillanos, y esto lo sabe cualquiera que haya leido algunas de sus múltiples historias locales tempranas, supieron muy pronto de la admiración que provocaba su ciudad, tanto en lo que se refiere a su ubi-

${ }^{3}$ Se trata de un refrán que llenaba de satisfacción, p. e., a Juan Mal Lara, como se advierte en su Philosophia vulgar (Sevilla, Hernando Diaz, 1568, fol. $6 \mathrm{r}-\mathrm{v}$ ), donde comenta: "Oyalo yo en Salamanca, y desseava bolver a Sevilla como a mi tierra, y por gozar de tal privilegio. Oyalo en Valencia, en Barcelona, y quanto mas lexos, mas desseo me añadia, hasta que començamos a gozar de las palabras del refrán".

${ }_{4}^{4}$ Reproduce el comentario de los viajeros más destacados Morales Padron, F., La ciudad del quinientos (de la serie "Historia de Sevilla"). Sevilla 1977, págs. 52 y ss.

${ }^{5}$ Algunos de estos mapamundis formaron parte de las exposiciones cartográficas que tuvieron lugar en distintas ciudades de Holanda en 1989. En cuanto a los escritorios, a los que se reproducen en lconografía ... I, núms. 44 y 45 y en lconografía ..., II págs. 64 y 65 , hay que añadir el fechado en 1611 que guarda una colección particular madrileña y que se expuso en Mueble español. Estrado y dormitorio (Madrid 1990), con el número 47 de catálogo (pág. 256). 


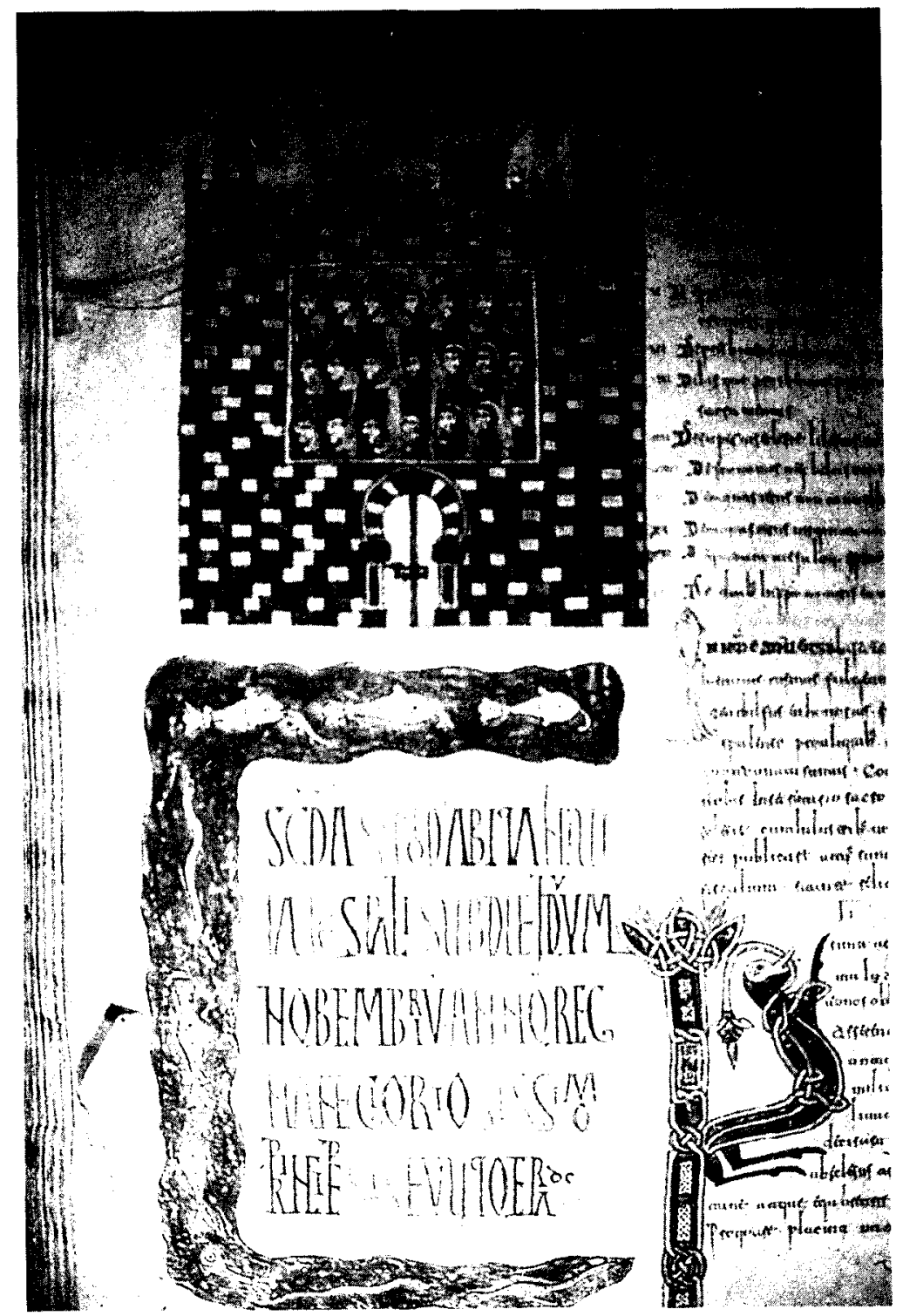

Fig. 1. Anónimo, "Sevilla". Códice Emilianense, siglo x. Biblioteca del Monasterio de San Lorenzo de El Escorial. 
cación o a algunos de sus monumentos más característicos, como en lo que respecta a la abigarrada sociedad que vivia en ella. Esto aumentó en ellos la conciencia de singularidad, y es una de las causas de que sea una de las ciudades españolas en las que durante toda la Edad Moderna, y hasta prácticamente nuestro dias, se puedan rastrear más expresiones de orgullo local. Frecuentemente este orgullo se manifestó - aunque a veces veladamente - de forma gráfica, y de ello vamos a tratar en las páginas que siguen.

En líneas generales se puede decir que —dejando aparte la cortees Sevilla la ciudad española que en mayor número de ocasiones fue objeto de representación artística en el Siglo de Oro. Aunque muchas de estas imágenes fueron realizadas por extranjeros y tienen su origen en la demanda de vistas de una población que casi todos habian oído ponderar y sólo unos pocos pudieron ver, hay una parte importante y significativa que se creó en la propia ciudad, y que en última instancia nos está hablando de la satisfacción de los sevillanos con su entorno.

La verdad es que la multiplicación de vistas generales se veía favorecida por la propia ubicación y por las características urbanas de Sevilla, que reunía todos los ingredientes para personalizar las distintas ideas de lo que a lo largo del tiempo se pensaba que tenía que ser una ciudad. Así durante la Edad Media, en la que se habia instalado la idea de que cualquier población debía ser ante todo un seguro frente a un entorno peligroso y agresivo, Sevilla prestó a los artistas unas espléndidas murallas que se convirtieron en eje fundamental de sus representaciones ${ }^{6}$. Pero en el siglo Xvı cambia la idea de ciudad, y se piensa que su importancia ya no le tiene que venir tanto de sus muros como de su abundante y variada población, de su riqueza, de su empaque arquitectónico y urbanístico, de su condición de centro importante de intercambios comerciales o de la existencia de núcleos destacados de poder político o reli-

- Un recinto amurallado y el rio son los elementos que componen la imagen más antigua que se conoce de Sevilla, una miniatura del Códice Emilianense de la Biblioteca del Escorial (siglo $x$ ). Trata de ella SiLva y verastegul, S., Iconografia del siglo $x$ en el Reino de Pamplona-Nájera. Pamplona 1984, pág. 410 y lám. XXIV. Estos dos elementos forman también parte fundamental de otras imágenes medievales de la ciudad, como la que aparece en el sello (siglos XIII-XIV) cuya matriz guarda el Instituto Valencia de Don Juan y del que se conserva una prueba en cera en el Ayuntamiento de Sevilla. Vid. Collantes DE TERAN, F., El patrimonio monumental y artístico del Ayuntamiento de Sevilla. Sevilla 1967, pág. 22, lám. 28. De la existencia de este tipo de sellos de interés para la iconografia de Sevilla ya se hizo eco D. Ortiz de Zúñiga en 1677, cuando escribió refiriendose a la antigua mezquita: "Y vese su imagen externa, con la de la torre, en los reversos de los sellos antiguos de la ciudad, que atestiguan esta vistosa muestra" (Anales eclesiásticos y seculares de la M.N. y M.L. ciudad de Sevilla. Sevilla 1677, pág. 21). 
gioso. Y Sevilla no sólo reunia todas estas características, sino que gracias a su ubicación y su estructura urbana fue capaz de integrarlas todas en una imagen que fue muy ampliamente divulgada en España y en el extranjero, y que durante todo un siglo convirtió a la población en paradigma de la ciudad moderna. Pinturas y estampas difunden la imagen de una urbe en las orillas de un rio cuyas embarcaciones y riberas dan fe de su enorme poderío económico y hacen sospechar un alto cosmopolitismo social, mientras que la abundancia de grandes edificios eclesiásticos y civiles nos habla de una gran concentración de poder politico y religioso ${ }^{7}$.

Se trata de un tipo de representación que se extendió muchísimo por Europa a través principalmente de libros y de estampas sueltas, y que al mismo tiempo debió de agradar a los propios sevillanos, si hemos de juzgar por lo muy amigos que se mostraron de utilizarla. De hecho su origen se encuentra en la propia Sevilla, y se data a mediados del siglo XVI, cuando Pedro de Medina publica su Libro de las grandezas y cosas memorables de España. Desde entonces se extendió claramente la conciencia de que la ciudad tiene una fachada - la occidental- mucho más interesante que cualquier otra y que permite comprender de un sólo golpe de vista - como explica Caro en una espléndida descripción-- ${ }^{8}$ la importancia y la belleza de la población. Esta conciencia arraigó tanto y tan pronto que cuando Felipe II visitó la ciudad en 1570 se modificó sustancialmente el trayecto habitual de las entradas reales con objeto de que ésta tuviera por escenario el Arenal ${ }^{9}$.

Las vistas generales creadas para el consumo interno fueron muy abundantes (siempre en relación con España) y se localizan en contextos muy diversos, todo lo cual directa o indirectamente nos habla del orgullo de los sevillanos por la ciudad en la que vivian. En ocasiones constituyen el tema principal de algunos cuadros, como los tres que en 1620 acordó

' Este tipo de representación se extendió mucho desde mediados del siglo xvı, como puede comprobar todo aquel que consulte los repertorios de iconografía de la ciudad. Enseguida dio lugar a dos modalidades: la que abarcaba toda la población, y aquella que únicamente reproducia una parte de Triana, el río y la fachada occidental de la ciudad. Este último fue un esquema que pronto se generalizó para la representación de importantes poblaciones, como Londres. Vid. WARNER, M., The Image of London. Views by Travellers and Emigrés. 1550-1920. Londres 1987, núms. 1, 8, 19, 28, etc. fol. 64 r.

\& Caro, R., Antigüedades y principado de la ilustrísima ciudad de Sevilla. Sevilla 1634,

${ }^{9}$ MaL LaRA, J., Recibimiento que hizo la M.N. y M.L. ciudad de Sevilla a ... don Phelipe N.S. .., Sevilla, Alonso Escrivano, 1570, fol. 41r: "Pues toda la fuerça del recibimiento se ponía, en la buena muestra del rio, y entrada de la ciudad". Veáse también LLEO CAÑAL, Nueva Roma. Sevilla 1979, pág. 174. 


\section{Lapítulo, rliiii. Dela muy infigne ciudad be Seutla fu antiguedad z nöbzea i muchas colas notrables oella.}

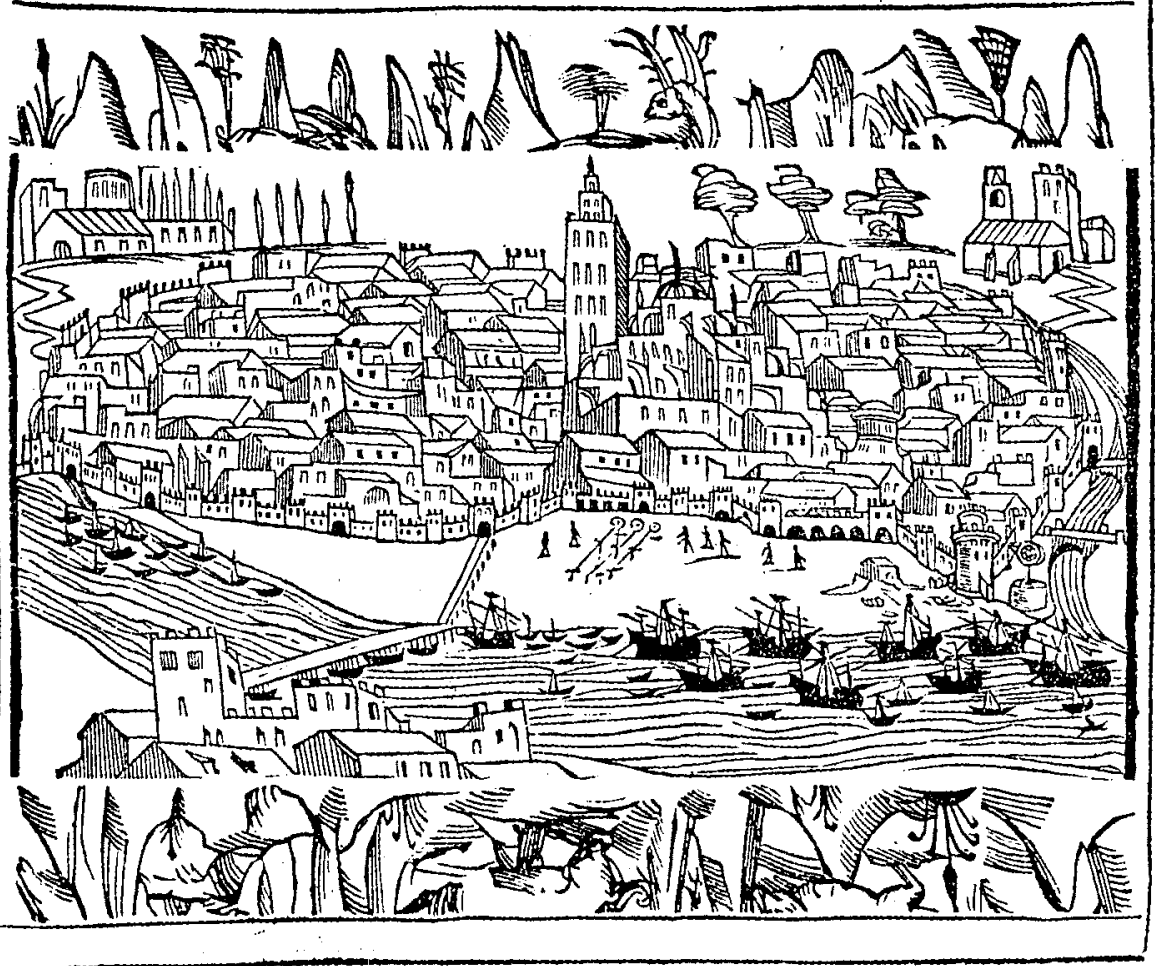

Fig. 2. Anónimo, "Vista de Sevilla". Pedro de Medina, Libro de las Grandezas y cosas meorables de España. Sevilla 1548.

Miguel de Esquivel pintar para el escribano del cabildo, o los cuatro que en 1610 se comprometieron a realizar Cristóbal de Vela y Juan de Quintanilla ${ }^{10}$. Pero mucho más significativo es observar la presencia de

10 Por su parte, Cristóbal de Vela y Juan de Quintanilla se comprometieron en 1610 a pintar "quatro ciudades de Sevilla". En algunos inventarios de bienes de viviendas sevillanas aparecen vistas de la ciudad. Asi, en la Casa de Pilatos habia en 1637 "un papel en que está pintada Sevilla puesto en un bastidor" y "una estampa de Sevilla en papel». Recoge estos datos Serrera, J. M., en su texto incluido en Iconografía ... II, págs. 71, 72 y 56. 


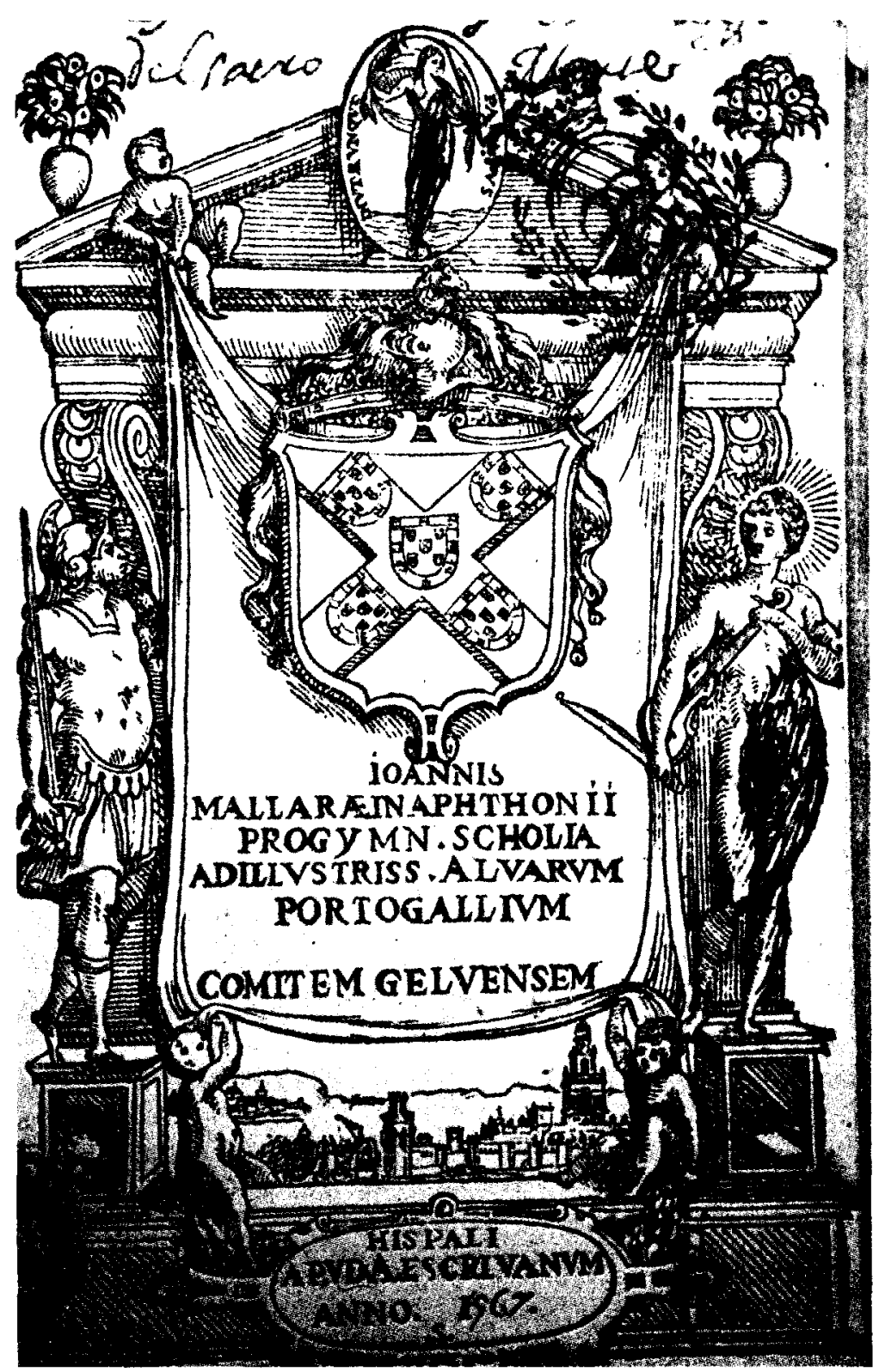

Fig. 3. A. Vázquez. Portada de J. Mal Lara, In Aphtonii progymm ... Sevilla 1567. 


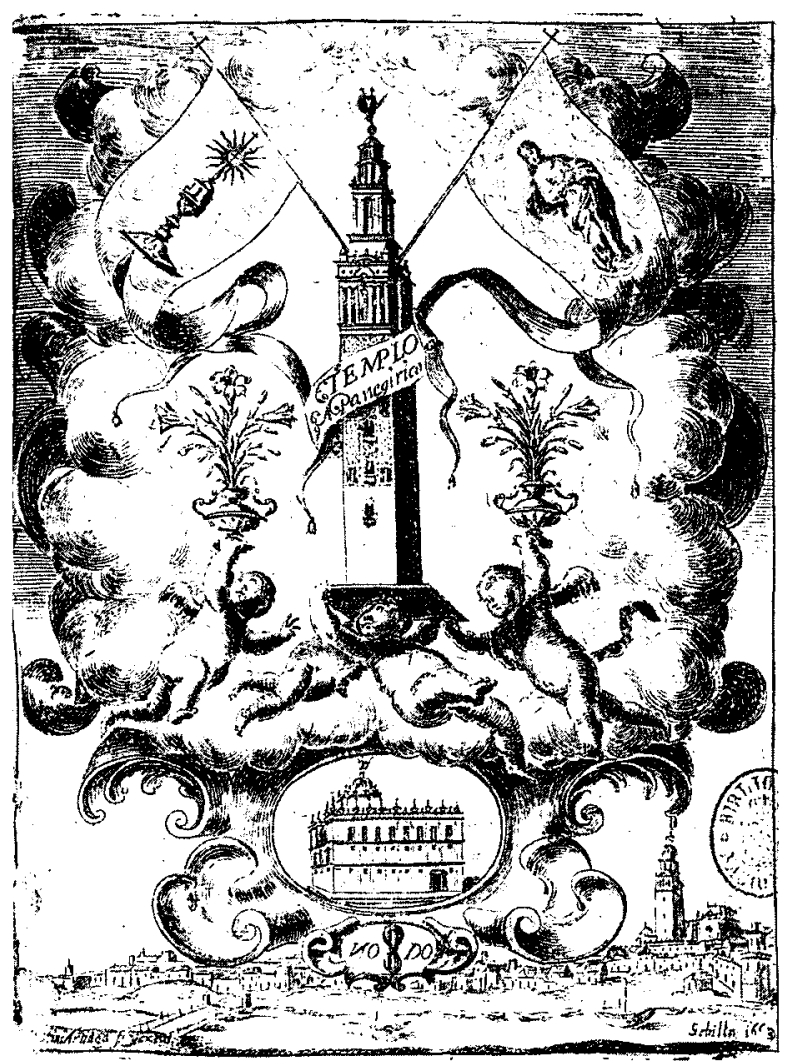

Fig. 4. M. de Arteaga. Portada de F. de la Torre Fartán, Templo panegírico... estrenando la grande fábrica del Sagrario. Sevilla 1663.

imágenes de la ciudad en portadas de libros publicados en ella, lo que sólo muy raramente ocurre en otras poblaciones. Aparece asi en una obra temprana como la Crónica del sancto rey don Fernando el Tercero (Sevilla 1551), en In Aphthonii progrymn scholia de Juan Mal Lara (Sevilla 1567) ${ }^{11}$, en la Regla del coro y cabildo de la S.I. Metropolitana de Sevilla (Sevilla 1658), en el Templo panegírico... estrenando la grande

1 La Crónica ... fue impresa por Domenico de Robertis. Sobre ella ha tratado PORTILlo MuÑoz, J. L., "Las ilustraciones de los impresos sevillanos del siglo XVI", Laboratorio de Arte, I (1988), pág. 81. En cuanto a la obra de Mal Lara, salió de las prensas de Alonso Escrivano, y su portada fue dibujada por Juan Bautista Vázquez el Viejo. Vid. Estella, M., "Juan Bautista Vázquez el Viejo y el Museo Lázaro", Goya, núms. 193-195 (1986-1987), pág. 121. 
fábrica del Sagrario (Sevilla 1663), de Fernando de la Torre Farfán, o en las Fiestas de la S.I. ... de Sevilla a ... San Fernando (Sevilla 1671), del mismo autor ${ }^{12}$.

Pero el orgullo local en la España del Siglo de Oro se alimentaba no sólo de la suntuosidad o de la belleza urbanas, sino también de la historia de la ciudad y de los hombres ilustres que la habian habitado. Y dado el carácter teocéntrico de la ideologia del momento, eran los santos - las grandes personalidades eclesiásticas aquellos de quienes más satisfechos podian sentirse sus conciudadanos. En Sevilla se produjo una alianza muy efectiva y de gran interés entre el amor por el entorno y el aprecio por la historia local; y asi, a partir del siglo XVI proliferaron las representaciones de tres héroes acompañados de vistas de la ciudad o de alguno de sus monumentos más característicos: nos referimos a las santas Justa y Rufina y a San Fernando. Aunque todos ellos poseian atributos iconográficos que hacian innecesarias las alusiones topográficas para su identificación, lo cierto es que los artistas sevillanos aprovecharon frecuentemente las posibilidades que les ofrecian para incluir referencias a su ciudad. Del santo rey nos indica Torre Farfán que se encontraban "repartidas en número casi infinito" las imágenes que le representaban "armado a la vista desta ciudad, y postrado el moro, entregando esta llave" "13; y este mismo autor utiliza precisamente la proliferación de este tipo de pinturas como prueba de que el suceso fue histórico ${ }^{14}$. Encuanto a las santas alfareras, en general aparecen acompañadas por la Giralda, a la que, se decia, salvaron de caer derrumbada por un terremoto; pero no faltan imágenes en las que aparecen con la ciudad de la que son protectoras ${ }^{15}$. Con el tiempo, la imagen de estas santas delante

${ }^{12}$ lconografía ..., II, núms. 3, 5 y 9.

is Torre Farfan, F. de la, Fiestas de la Santa Iglesia de Sevilla al culto ... de San Fernando. Sevilla. Vda. De Nicolás Rodríguez, 1671, pág. 54. Entre las imágenes más antiguas de San Fernando con iconografía de Sevilla de las que tenemos noticia figura la que aparecia en un arco triunfal que se levantó en Madrid por la llegada de Ana de Austria, y que López de Hoyos describe así: "El rey don Fernando Tercero, que llaman el sancto, armado a la antigua española, capacete con corona, y coraças, con su espada desnuda en la mano derecha, y en la yzquierda la torre de la yglesia mayor de Sevilla". Real apparato, y sumptuoso recebimiento con que Madrid rescibió a ... D. Ana de Austria ... Madrid, luan Gracián, 1572 (Apud. Simón Diaz, J., Fuentes para la historia de Madrid y su provincia. Madrid 1964, pág. 63a).

${ }^{14}$ Idem, pág. 59: “Ayudóse siempre esta tradición para no descaecer de su fundamento, con la realidad invencible, de las pinturas, ya antiguas, ya modernas ...Pintura tan repetida de la devoción de los sevillanos, que dudo, que aya cassa donde entre los adornos, ya magníficos, o ya vulgares, no se venere esta demostración".

15 A los numerosos ejemplos que aparecen en lconografía ... I y || queremos sumar unos pocos de cierto interés. Así, la imagen de las santas con la Giralda se puede rastrear desde la primera mitad del siglo XVI, en que aparece adornado documentos municipales, 


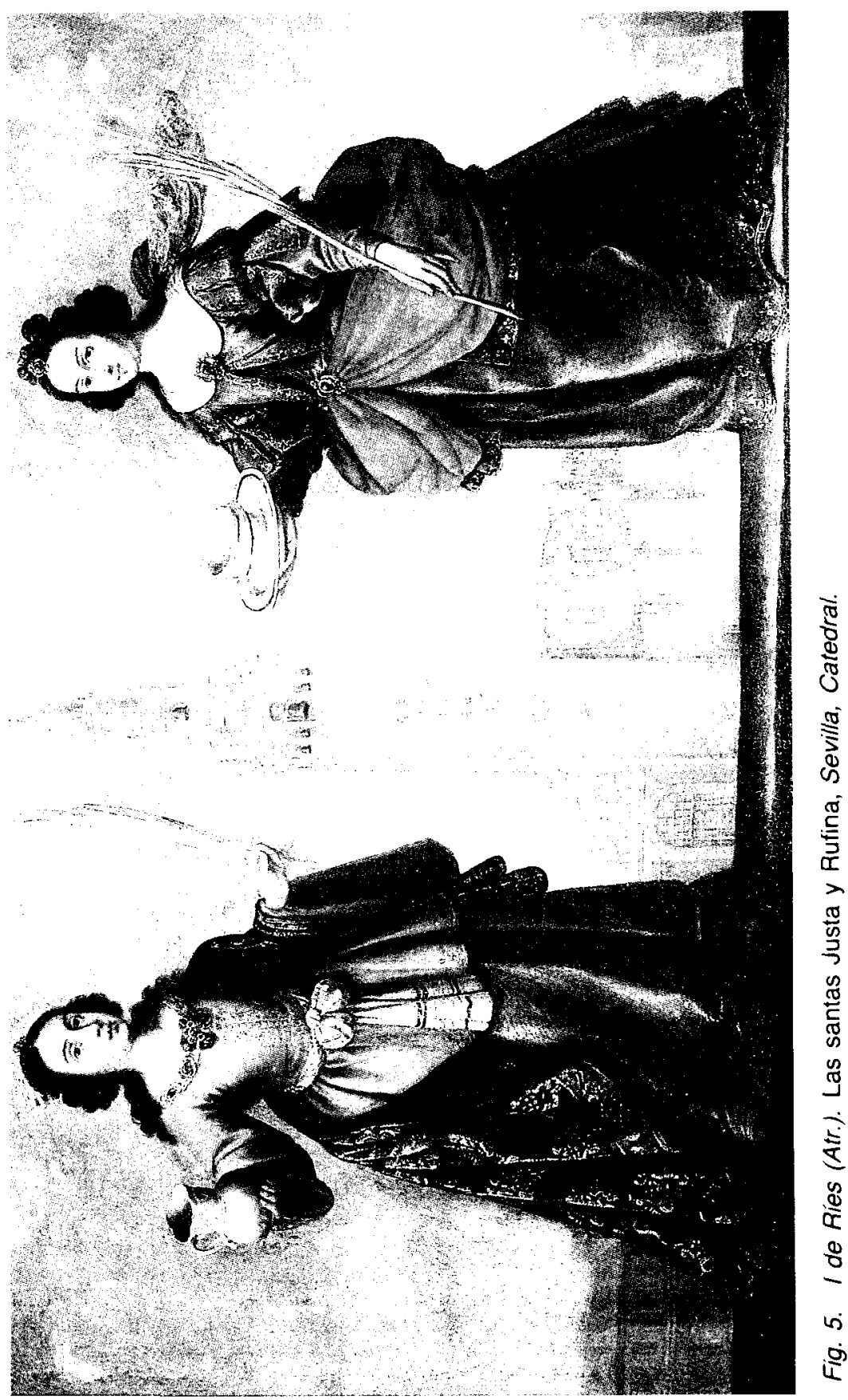


- con la ciudad se convirtió en una especie de arquetipo visual que creemos está en el origen de los numerosos retratos sevillanos del siglo $\mathrm{xIX}$ en los que el modelo tiene como fondo monumentos característicos de la población, como la Giralda o la Torre del Oro ${ }^{16}$.

A la hora de preguntarnos sobre las causas de esta relativa abundancia de vistas generales realizadas para el consumo interno no sólo hemos de contar con un cierto narcisismo local o con la utilidad que en ocasiones tienen para identificar a los personajes a los que a veces acompañan, sino que hemos de tener también en cuenta que su peculiar situación geográfica o la existencia de edificios de acusadísima personalidad hizo posible que se formara una imagen de la ciudad reconocible por todos y a la vez susceptible de ser sometida a variados y diferentes procesos de esquematización, lo que la hacía apta para ser empleada en cualquier contexto formal.

Al lado de obras en las que se representaba el conjunto de la ciudad convivian otras que tienen por tema algunos de sus sectores o monumentos más característicos. El Arenal, por ejemplo, que tanto fascinó a los literatos, aparece representado en dos interesantísimos cuadros de principios del siglo XVII de la Hispanic Society, y en algún azulejo; y la Alameda de Hércules sirvió frecuentemente de inspiración a los pintores ${ }^{17}$. Incluso habia en la ciudad algún artista presumiblemente especializado en la pintura de vistas urbanas, como el flamenco Juan van Mol, que aparece documentado desde 1636 y del que el Conde del Águila poseía una vista de la Alameda y una representación de la Cruz del Campo ${ }^{18}$. Este tipo de obras era probablemente más consumido de lo

\footnotetext{
algunos de los cuales se exhibieron en la Exposición Valdés Leal y el arte retrospectivo. Sevilia 1923. También son dignas de destacarse algunas imágenes de las santas realizadas en distintos medios en torno a 1600 y que se reparten por la Catedral de Sevilla (Iglesia del Sagrario, Sillón del Secretario, etc.). Igualmente es de bastante interés un lienzo que representa a estas ilustres alfareras y que alguna vez ( $p$. e. CAMON, J., Pintura española del siglo XVII. Madrid 1977, pág. 296) se han creido de Zurbarán. En realidad más parecen - a juzgar por fotografia - obra de alguno de sus discipulos, como Ignacio de Ries. Otras notables imágenes de las santas no recogidas en los repertorios citados son las esculturas de la Iglesia del Salvador de Sevilla o del Convento de Don Juan de Alarcón de Madrid, o una estarnpa parisina del siglo XVii que guarda la colección Plata de Sevilla.

${ }_{16}$ Algunos de estos retratos aparecen en AA.VV., Iconografia de Sevilla, 1790-1868. Madrid 1991 (en prensa).

17 Iconografía... I, núms. 89-93; Iconografía ..., II, núms. 137 y 139.

${ }^{18}$ KinKEAD, D. T., "Pintores flamencos en Sevilla en la segunda mitad del siglo XVI"», Archivo Hispalense, núm. 195 (182), pág. 49. Cabria preguntarse si la "Vista de Sevilla" de propiedad particular barcelonesa y alguna vez atribuida a Martínez de Mazo (lconografía ..., I, núm. 95), es de Van Mol o alguno de sus compatriotas establecidos en la ciudad, pues su estilo es flamenco.
} 
que pensamos en Sevilla, donde más del $13 \%$ de los cuadros localizados en inventarios del siglo XVII se definen como "paises" ${ }^{19}$.

Pero el monumento del que más orgullosos se sentían los sevillanos era la Giralda, y de ello dieron numerosas pruebas. Se trataba de una torre que fue extraordinariamente apreciada desde su edificación, y ya en épocas tempranas se convirtió en un verdadero símbolo ciudadano. Incluso corrian -y no sólo en Sevilla - relatos de carácter legendario sobre lo muy estimada que fue siempre, como el que asegura que tras la conquista cristiana de la ciudad, el rey moro pretendió derribarla, lo que no pudo hacer debido a las terribles amenazas de San Fernando. Uno de los que nos lo cuenta es Lope de Vega, quien en La divina vencedora escribe:

«El gran Miramamolín, / .../ que les deje, le demanda,

derribar la gran Mezquita/ con la torre ilustre y alta / .../

y él (Fernando III) dijo tales palabras, /

que por un ladrillo sólo / que a la Mezquita faltara,/

cien mil vidas quitaría, / tanto a sevilla estimaba»" ${ }^{20}$.

En el siglo XVı no faltaba en ninguna de las listas de las «maravillas» de España, y su silueta se convirtió en elemento fundamental del perfil de la ciudad. Así, Mal Lara, al narrar la entrada de Felipe II, asegura que "lo que más muestra dava del edificio de la ciudad, era la yglesia con su alta torre" ${ }^{21}$. La Giralda sirvió con su sola presencia para aludir al conjunto de la población a la que pertenece, lo que le dio categoría de símbolo. Su aparición al lado de personajes tan representados como San Fernando o Santa Justa y Rufina o su conversión - junto con las azucenas- en símbolo del cabildo catedralicio o en puzón de plateria ${ }^{22}$, hizo

19 Martin Morales, F., "Aproximación al estudio del mercado de cuadros en la Sevilla barroca. 1600-1670", Archivo Hispalense, núm. 210 (1986), pág. 152.

${ }_{20}$ Obras de Lope de Vega, t. IV, ed. E. Cotarelo. Madrid 1917, pág. 646a. La fortuna literaria e iconográfica de la Giralda ha sido inmensa. Algunos de sus hitos fundamentales aparecen en FalCón, T., La Giralda. Rosa de los vientos. Sevilla 1989. En relación con este tema puede verse el agudo trabajo de SerRERA, J.M., El "quid" de la Giralda o la Giralda "kitsch". Sevilla 1984.

${ }_{21}$ MAL LARA, El recibimiento..., Op. cit., fols. 30v-31v.

${ }^{22}$ Los citados repertorios iconográficos dan numerosos ejemplos de la actuación de la Giralda como símbolo del cabildo o como atributo de los santos. En cuanto a su conversión en punzón de platería, véase Sanz Serrano, M. J., "Punzones de la ciudad de Sevilla hasta fines del siglo XVl", Revista de Arte Sevillano, núm. 2 (1982), págs. 3-9. En alguna ocasión fue incluso empleada como marca de impresor, dato sobre el que llamó la atención $K$. Wagner en su artículo, "La Giralda como marca de impresor", Homenaje al Profesor $D$. Hernández Diaz, t. I, Sevilla, 1982. 


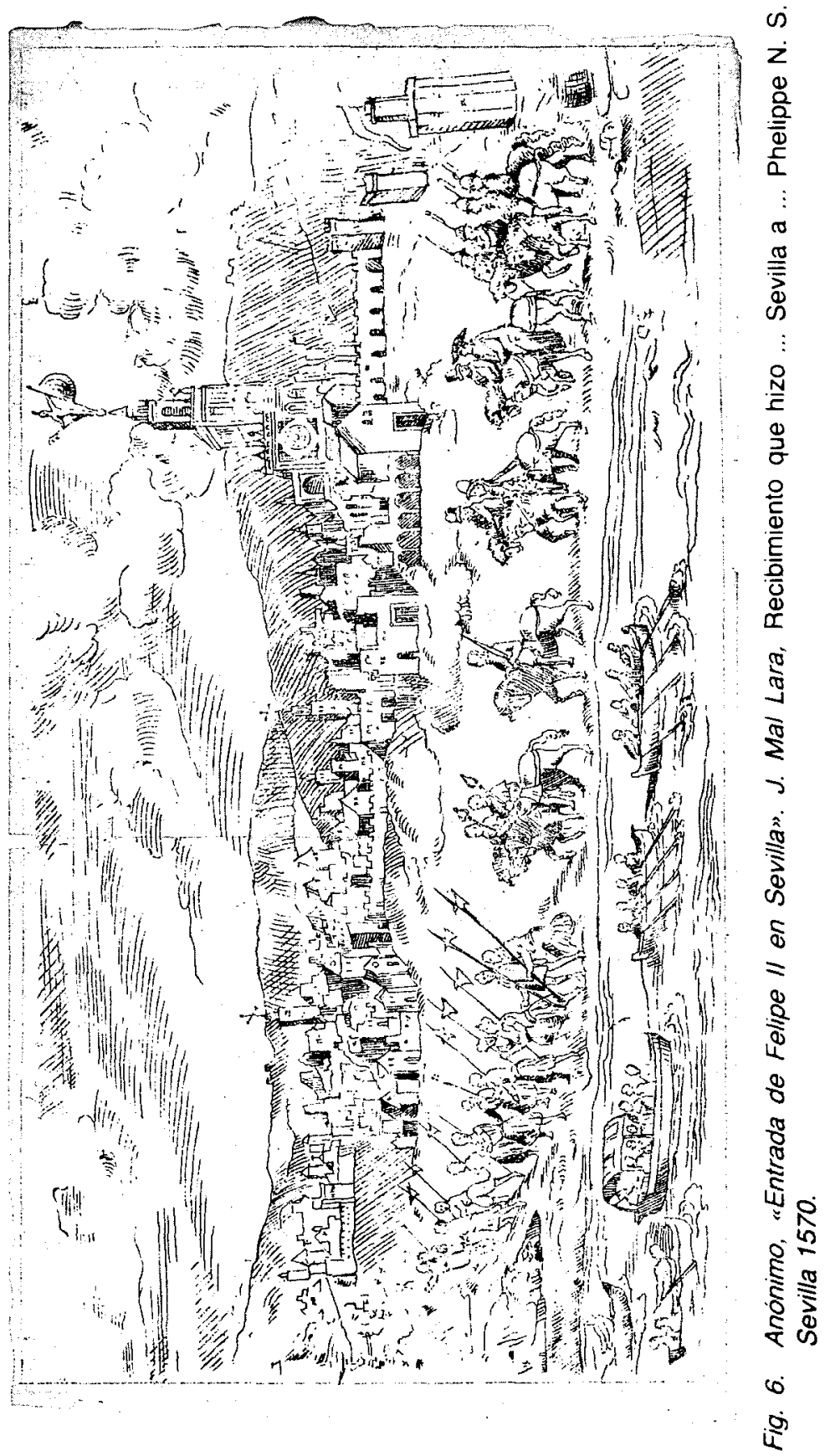




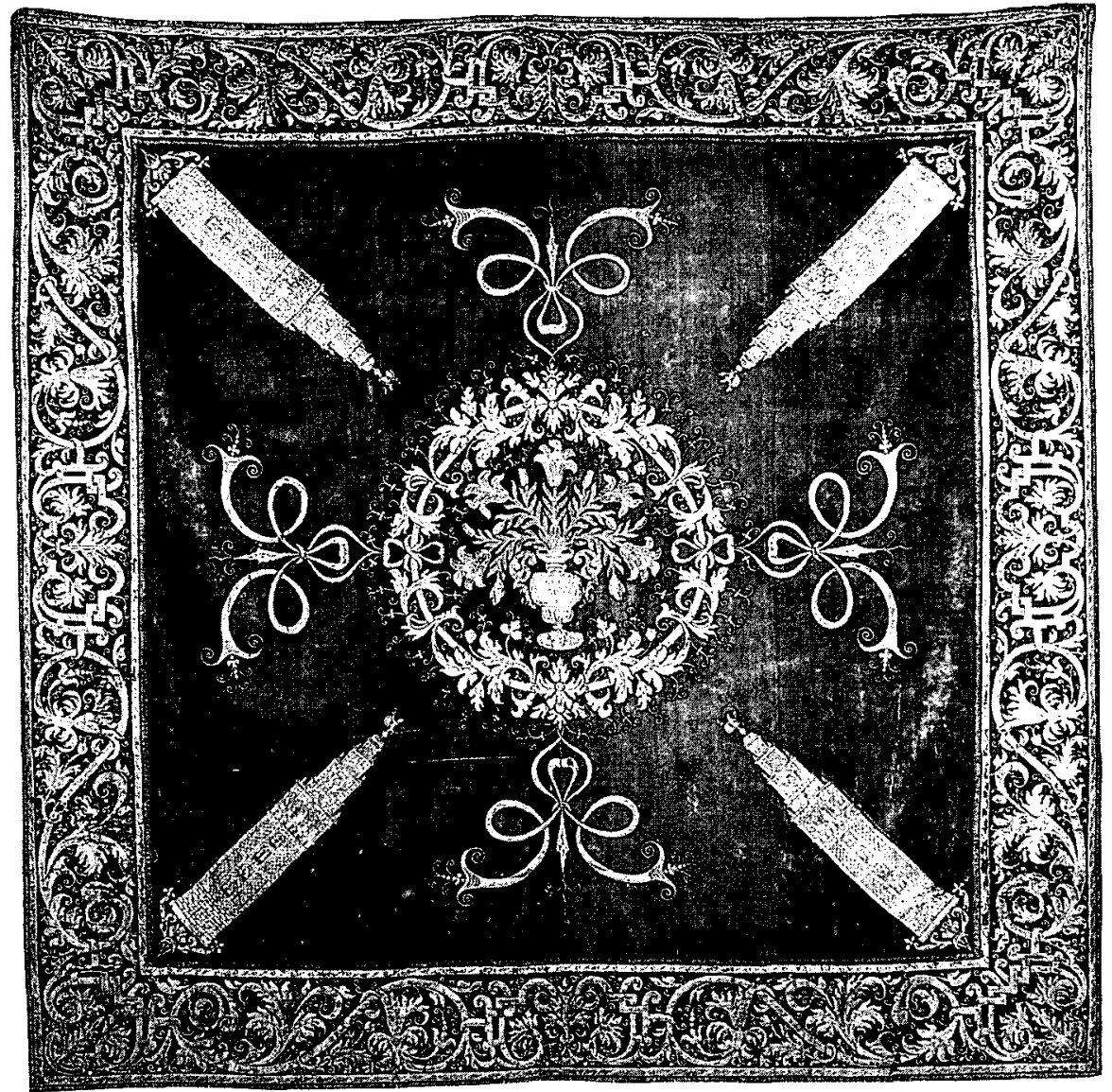

Fig. 7. Repostero de finales del siglo xvi. Sevilla, Catedral.

que se multiplicase extraordinariamente su presencia en la población, y revela una clara complacencia de los sevillanos para con su torre. De lo mucho que estos admiraban y lo muy puntillosos que eran los españoles a la hora de defender las glorias y bellezas de sus respectivas ciudades da fe una divertida carta del epistolario con el que abriamos este artículo, en la que Caro comenta:

"Yo conoci aqui en Sevilla un toledano que, porque yo dije que la torre de Sevilla era de las mejores cosas que habia en España, siendo 
cosa que consta ad oculum, se enfureció y dijo que no valía nada, y que las campanas de aqui, para con las de Toledo, eran unos cencerros" ${ }^{23}$.

También fue repetidamente representada la Capilla Real de la Catedral, sobre todo a raíz de la canonización de San Fernando, cuyos restos albergaba. Las imágenes de esta construcción no sólo se prodigaron en Sevilla ${ }^{24}$, sino que se documentan también en otras poblaciones, como Madrid. Así la Condesa de Villahermosa poseía en 1702 "una miniatura de la Capilla del Santo Rey don Fernando, original de Juan Valdés", y casi veinte años antes, en 1685, aparece un cuadro de igual tema y autor en propiedad de don Pedro Núñez de Guzmán, del Consejo de Castilla ${ }^{25}$.

Hasta ahora hemos visto cómo el estudio de la ilustración de los libros, de la formación de la iconografía de los santos vinculados con la ciudad, de los símbolos que eligieron algunos organismos locales, o de las colecciones de cuadros, sugiere que los sevillanos a menudo expresaron su orgullo de serlo de manera iconográfica, prodigando las representaciones de sus héroes y sus monumentos más característicos. Hay incluso algún otro testimonio que nos habla en el mismo sentido. Como se ha señalado en varias ocasiones ${ }^{26}$, los grandes pintores de Siglo de Oro no fueron muy amigos de aprovechar su magnifico entorno urbano para ambientar en él sus composiciones, ni siquiera las de tema claramente costumbrista. La explicación de este fenómeno creemos que en parte hay que buscarla en el método de trabajo generalizado entre los artistas españoles, los cuales se habian acostumbrado a no salir del taller para trabajar, y a resolver los elemientos topográficos de sus cuadros mediante un lenguaje en general muy codificado y que procedia frecuen-

${ }^{23}$ Caro, R., Varones Insignes... Op. cit., pág. 116. Está dirigida a Uztárroz.

${ }^{24}$ Morales, A. J., "Iconografia de la Capilla Real de Sevilla", Archivo Hispalense, núm. 221 (1989), págs. $117-123$

${ }^{25}$ Del cuadro de la Condesa de Villahermosa da noticias Agullo, M., Noticias sobre pintores madrileños de los siglos xVI y xvil. Madrid 1978, pág. 70. En cuanto al de Pedro Núñez, habla de él FAYARD, J., en Los miembros del Consejo de Castilla. Madrid 1982. No son estas las únicas representaciones de la Capilla Real que se pudieron ver en Madrid. Asi, una didascalia del auto de Calderón El Santo Rey, indica que el retablo que presidiria la escena final había de ser "a imitación de la Capilla Real de los Señores Reyes en Sevilla, de que se dará planta" (Serrera, J. M., "Murillo y la escuela sevillana", en AA.VV., El Siglo de Oro de la pintura española: nuevas perspectivas. Madrid 1991).

${ }_{26}$ Véase, por ejemplo, Calvo CASTELLON, A., Los fondos arquitectónicos y el paisaje en la pintura barroca andaluza. Granada 1982; O Rodriguez G. DE Ceballos, A., "Los fondos arquitectónicos en la pintura del Siglo de Oro", en AA.VV., El Siglo de Oro de la pintura española. Nuevas perspectivas. Madrid 1991. 

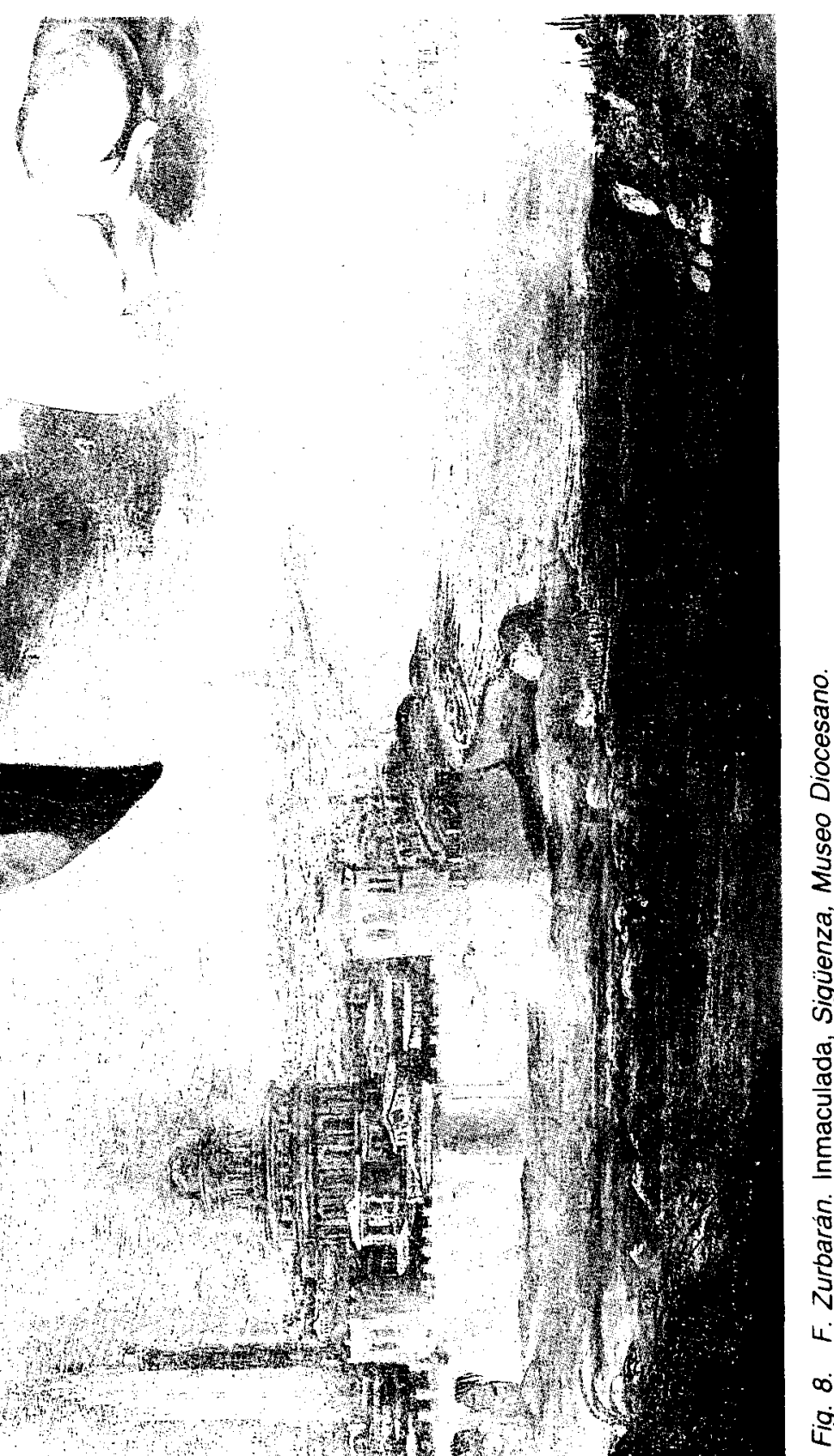
temente de libros de arquitectura y de estampas. Por ello, la utilización de alusiones a la Giralda o a Sevilla como simbolos de las letanías en algunas "Inmaculadas" de Pacheco o Zurbarán es un hecho insólito en el contexto español, y creemos que muy expresivo del amor de estos artistas y de su público para con la ciudad ${ }^{27}$.

La fiesta urbana ha sido la manifestación colectiva por excelencia del Antiguo Régimen. A través de la ceremonia, el rito y la jerarquización de las grandes celebraciones, las sociedades han sabido identificarse como colectividad en la que cada uno de sus componentes tiene una función definida que cumplir. De hecho, una de las máximas expresiones del fuerte sentido de comunidad que arraigó en las ciudades españolas durante la Edad Moderna es precisamente la proliferación de costosas celebraciones que conmemoraban algún hecho destacado de la vida civil o religiosa, $y$ en las que participaba ordenada y jerarquizadamente todo el cuerpo social. Un repaso a la relación ya clásica de Alenda es suficiente para apreciar la cantidad e importancia de las fiestas que tuvieron lugar en Sevilla en el periodo que aquí nos ocupa ${ }^{28}$. Pero aunque la proliferación y brillantez de este tipo de actos puede ser indicativo de la existencia de importantes aglutinantes institucionales o ideológicos capaces de poner en movimiento a todos los estratos sociales en un proyecto comunitario, lo que aquí nos interesa no es demostrar la variedad, riqueza, magnificencia e interés de las celebraciones sevillanas, sino llamar la atención sobre la frecuencia con que en este tipo de actos aparecieron representaciones de la población o de alguno de sus monumentos más característicos.

${ }^{27}$ Aparte del caso de las Inmaculadas, bien conocido por todos, queremos destacar aqui la existencia de algunos cuadros cuyos fondos parecen inspirados en el paisaje urbano sevillano, como algunos de los lienzos sobre la vida de San Francisco de Paula pintados por Lucas Valdés y sobre los que se dio noticia en Iconografia... II, pág. 55; los anónimos de la primera mitad del siglo xvII que narran episodios de la vida de San Juan de Dios y guarda el Museo de Bellas Artes de Sevilla, o la serie de episodios bíblicos firmada en 1662 por Francisco Gutiérrez (Villagarcía de Campos, Colegiata), en cuyas torres y puertas de los fondos se ha querido ver alguna vez un reflejo de la Giralda y las murallas hispalenses. Sobre esta última serie véase SoriA, M. S., "Velázquez and Vedute Painting in Italy and Spain. 1620-1750", Arte Antica e Moderna, t. 16 (1961), pág. 441.

${ }_{28}^{28}$ La fama de la vistosidad y magnificencia de las fiestas sevilianas habia trascendido al resto de España. Son numerosos los testimonios que lo prueban, y entre ellos podemos citar el siguiente comentario de Garcia Salcedo Coronel a la "Canción" de Góngora por una fiesta en el Colegio de San Hermenegildo: “Celebróse su dedicación, y la translación de una Reliquia de este Invictísimo Mártir, con notable magestad, y grandeza, en que esta ciudad siempre se adelanta a todas las de España". Tomo segundo de las Obras de Luis de Góngora, comentadas por Don Garcia de Salzedo Coronel. Madrid, Diego Diaz de la Carrera, 1648, pág. 164. 
En 1570 visitó Felipe II la ciudad, y entre las grandes estatuas que se colocaron en las murallas figuraba una representación de Sevilla, que tenía «la cabeça torreada (...), en la mano yzquierda la torre de la Yglesia mayor desta ciudad, por ser todo su cuydado la religión" ${ }^{29}$. En realidad no era raro que entre las figuras que daban la bienvenida a un ilustre visitante figure la alegoría de la ciudad, ni tampoco que ésta adoptase la forma de matrona torreada. Pero lo que no era habitual es que portara un objeto - en este caso la Giralda - que sirviese para identificar inequivocamente a la población.

Dos años más tarde nació el príncipe Fernando, y para celebrarlo el Cabildo Municipal sacó por la plaza de San Francisco un carro triunfal en cuyo extremo "yva la torre de la yglesia mayor de Sevilla, hecha de madera y lienço al natural»". El carro estaba habitado por Sevilla, España, el rio Betis, la reina, su hijo, la Fe, la Fama y el Mundo, que supuestamente sostenian un diálogo sobre la vocación católica y ecuménica de la monarquia española y sobre la voluntad de Sevilla de servir a sus reyes y sus propósitos ${ }^{30}$. Esta estructura estaba precedida por tres damas vestidas «a lo romano» y que representaban la Contratación, la Aduana y la Casa de la Moneda.

Las entradas o entronizaciones de reyes o los nacimientos de príncipes eran los acontecimientos que por su naturaleza mejor se prestaban a dar lugar a celebraciones promovidas esencialmente por instituciones civiles locales; y por lo tanto no sorprende demasiado encontrar en ellos representaciones de la propia ciudad. Lo que si es más raro es hallarlas en fiestas organizadas por comitentes privados. Este fue el caso, por ejemplo, de las que tuvieron lugar en 1610 con motivo de la beatificación de Ignacio de Loyola, y que, lógicamente, corrieron sobre todo a cargo de los poderosos jesuitas. Uno de sus actos fundamentales fue una justa poética, que se anunciaba mediante un cartel «impreso en tres pliegos de Marca Real». El primero de ellos to "ocupava una estampa de singular invención, no sólo propria del Santo, mas también de la lusta. Porque

29 MAL LARA, J., El recibimiento... Op. cit., fol. $27 \mathrm{~V}$.

30 AnONIMO, Relación de las Sumptuosas y ricas fiestas, que la insigne ciudad de Sevilla hizo, por el felice nascimiento del príncipe nuestro señor. Y por el vencimiento de la batalla naval, que el serenissimo de Austria ovo, contra el armada del Turco. Sevilla, Hernando Diaz, s.a., 1572, fols. 8v-9v. La ciudad aparecía también en el carro de los Carpinteros y Toneleros, donde se la representaba como “donzella muy ricamente vestida, y en la mano una coraçón abierto, y dentro del el nombre del principe escripto con cifra de oro" (fols. 21v-22r). El impreso incluye una estampa en madera que representa un sector de la ciudad con cuatro de sus santos, y que no aparece en los repertorios de iconografía de Sevilla. Probablemente su matriz data de finales del siglo xv o principios del xvi. 
en medio de una gallarda tarja, sobre unos lexos y campo de la ciudad de Sevilla, y de su arenal y rio, puestos en muy artificiosa perspectiva, se vía en pie el glorioso y resplandeciente Ignacio" ". Cabe preguntarse si el autor de esta estampa no sería Francisco de Herrera "el Viejo", quien firmó la que forma la portada de la relación de las fiestas. Todo indica que la ciudad estaba representada según el esquema que iniciara Pedro de Medina, y al que ya hemos hecho alusión. Pero lo más interesante de la imagen es el hecho de que la inclusión en ella de Sevilla no era, ni mucho menos, imprescindible (no así la del santo y los atributos que le rodeaban), y de hecho, en ninguno de los carteles de este tipo que conocemos de la España de esa época aparecen alusiones topográficas. Sólo en el caso de Valencia hemos observado (y seguimos hablando del contexto español) un empeño similar en incluir en las fiestas referencias a la propia ciudad.

No fue la del cartel la única imagen de Sevilla que apareció en las fiestas jesuíticas. Así por ejemplo, un lugar tan querido y representado por los sevillanos de la Edad Moderna como la Alameda, era el tema central del “jeroglíico" que envío el licenciado Antonio Villagrán al certamen poético. Con él se quería significar «El provecho de la Religión de la Compañia, que alcança a todos; a los árboles de la Alameda de la iglesia, y las fuentes, que son las Religiones". Su descripción es la siguiente: "Pintura: una Alameda con las fuentes, y las colunas de Hércules; y sobre ellas un lesus, con un PLUS ULTRA, y una fuente, que nace por una quiebra de un monte alto, cuyas aguas vienen a dar sobre todo el Alameda: y dize la letra en latín: Monimenta saxorum sublimitas eius; aquae eius fideles sunt. $Y$ en Romance: Por una quiebra nacio / Inació con tal pujança/que a todos el agua alcança" ${ }^{32}$.

Durante el Barroco se desarrolló en numerosas zonas europeas un nacionalismo (a veces localismo) que tuvo una destacada dimensión religiosa. Los distintos paises no sólo se dedicaron a exaltar santos o héroes religiosos locales, sino que hicieron también suya la defensa de cuestiones particulares relacionadas con el credo y el dogma. La relación entre sentimiento nacionalista y las peculiaridades regionales del culto o de la historia eclesiástica era tan estrecha que las autoridades civiles y eclesiásticas españolas, por ejemplo, trataron de impedir que se abrieran excesivos procesos de beatificación o canonización de indígenas ameri-

31 LuQue FajaRdo, F., Relación de la fiesta que se hizo en Sevilla en la Beatificación del Glorioso S. Ignacio... Sevilla, Luis Estupiñán, 1610, fol. 15v.

32 idem, fol. $117 \mathrm{~V}$ 


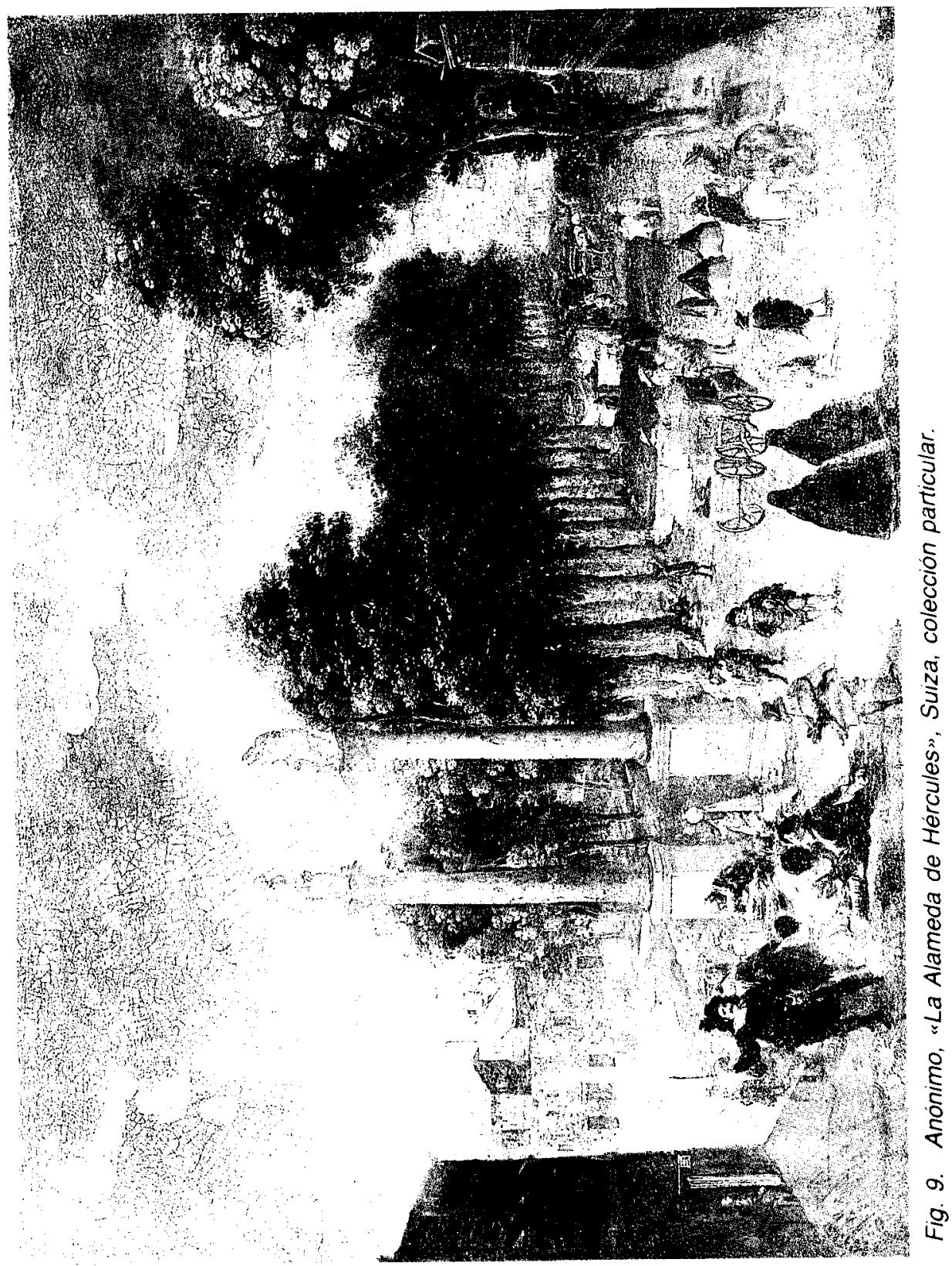


canos para evitar que se creara una conciencia de "nación" en ese continente. En la península el sentimiento nacionalista se alimentó presionando para que Roma elevase a los altares a santos locales (Isidro, Teresa, Ignacio, Francisco Javier, Luis Beltrán, Juan de la Cruz, etc.), y promoviendo la adhesión de la población a ciertas devociones. Entre esto último destacan las acciones encaminadas al reconocimiento del dogma de la Inmaculada Concepción, un tema que se consideró de interés estatal y que logró por momentos aglutinar a casi todos los españoles en una causa común. Y fue precisamente en Sevilla donde, a raíz de la publicación en 1615 de un escrito en contra de la creencia, se levantó una de las más importantes campañas populares en favor de la Inmaculada, que se personalizó en la figura de Miguel Cid y tuvo como expresiones no sólo la aparición de una gran cantidad de escritos sobre el tema, sino también la organización de numerosas fiestas que celebraban la bula que promulgó en 1616 Paulo $\mathrm{V}^{33}$. De alguna de estas fiestas nos ha quedado testimonio iconográfico, como el impagable lienzo de Roelas que guarda el Museo de la Pasión de Valladolid, una de las escasísimas obras españolas de ese siglo que describe lo que debía de ser el ambiente de las numerosas celebraciones ${ }^{34}$. No es ninguna casualidad que narre un acontecimiento ocurrido en Sevilla, pues la ciudad siempre se mostró ardiente defensora de la Inmaculada y bastante amiga de dejar constancia plástica de este amor. Así, de las paredes del Archivo de la Catedral cuelga un lienzo que representa una fiesta inmaculadista de hacia 1660 que tiene lugar en el exterior de la Iglesia Mayor ${ }^{35}$. $Y$ esto por no hablar de las incontables "Inmaculadas" (algunas, como se ha dicho, con referencias gráficas a la ciudad), que produjo la escuela sevillana.

En algunas de las celebraciones que en 1616 y 1617 se hiceron por el asunto del que hablamos no faltaron alusiones gráficas a la ciudad. Asi, la máscara que organizaron los plateros aparecia encabezada por la Fama y "Sevilla, armada de un coselete... El tocado que formava edificio murado con las torres y capiteles que tanta ciudad contiene... Llevávanla

33 Un interesante y actualizado estudio sobre la iconografía y el culto de la Inmaculada en el periodo que nos ocupa lo ofrece StratTon, S., "La Inmaculada Concepción en el arte español", Cuadernos de Arte e lconagrafia, t.l, núm. 2 (1988), págs. 1-27.

34 Iconografía ... I, núm. 54.

${ }^{35}$ Iconografía ... II, núm. 258. En el contexto español, esta relativa riqueza de representantes de fiestas inmaculadistas sólo tiene parangón con el libro de Valda que narra literaria y gráficamente las celebraciones valencianas de 1622. Véase PEDRAzA, P., Barroco efimero en Valencia. Valencia 1982. En este sentido, también es digno de destacar el dibujo de Herrera el Mozo que representa una composición arquitectónica realizada para unas fiestas de la Inmaculada, y que guarda el Museo de los Uffizi. 


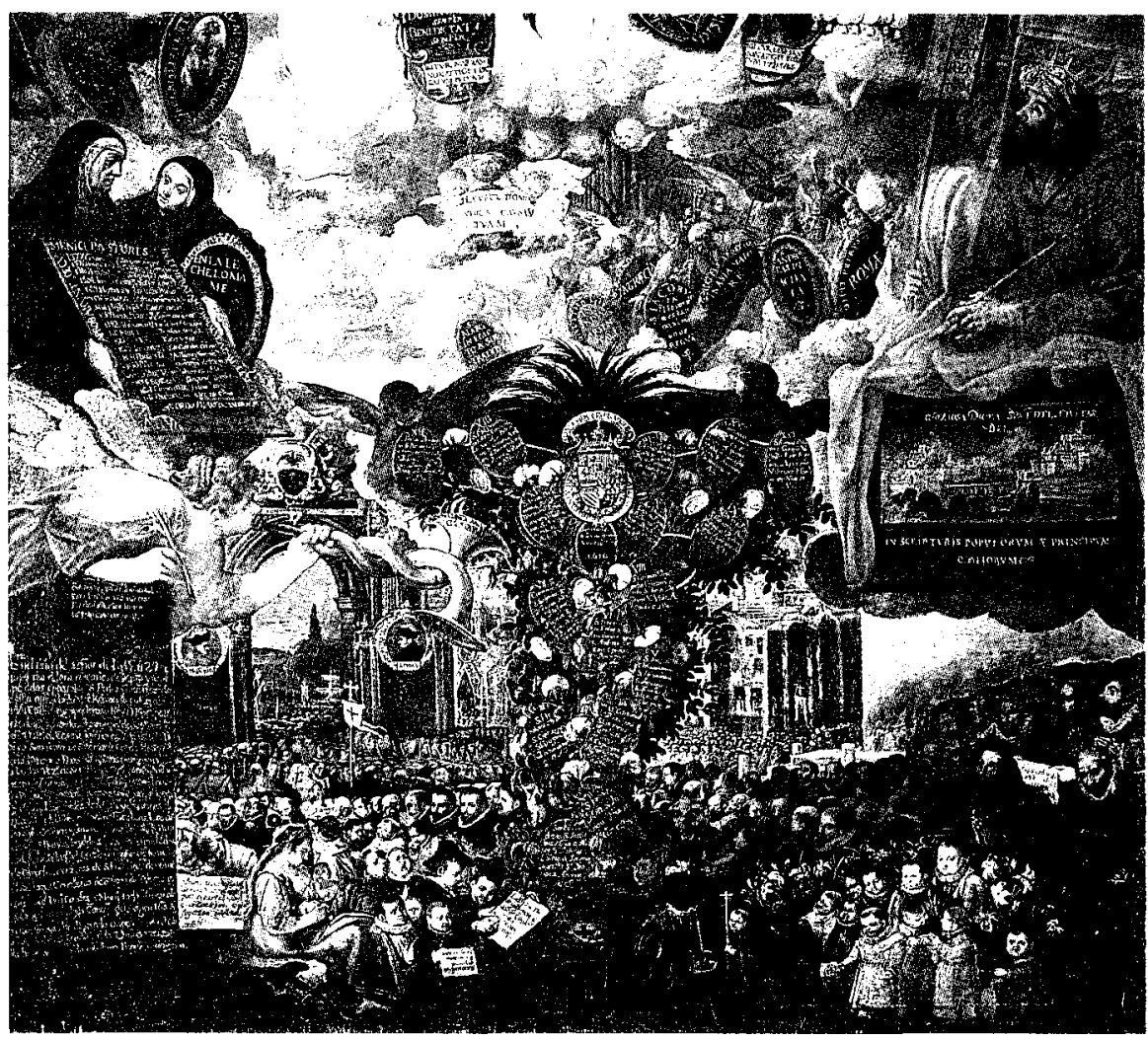

Fig. 10. J. Roelas. "Alegoria de la Inmaculada”, Valladolid, Museo de la Pasión (Detalle).

en un palafrén ricamente encubertado, Hércules y lulio César fundador suyo el uno, y reedificador el otro" ${ }^{36}$.

La referencia a Sevilla se hizo casi obligada en las numerosas fiestas que se celebraban en la ciudad, lo que no encuentra apenas parangón con lo que ocurría en el resto de España. En algunas ocasiones aparecen incluso sin apenas motivo que lo justificara. Asi, para la celebración de la canonización de San Andrés Corsino se montó en el testero de la iglesia del convento del Carmen un risco que aludía al Monte Car-

36 Anonimo, Copia sexta, que da cuenta de la máscara que los artistas plateros hizieron (por la Inmaculada). Sevilla, Gabriel Ramos Bejarano, 1617, fol. 1v. 
melo y a los montes del Delfinado, y que aparecía rodeado por las representaciones de los cuatro continentes y por un rio en el que se reflejaba la Giralda ${ }^{37}$.

Pero si hubo unas fiestas españolas que actuaron como excusa para multiplicar las alusiones iconográficas a la ciudad que las organizaba, ésas fueron las que tuvieron lugar en 1671 en Sevilla en celebración de la canonización de San Fernando ${ }^{38}$. A raíz de la epidemia de 1649 (entre otros factores), la población había perdido gran parte de su poderío demográfico y económico, y se había tenido que acostumbrar, aunque de mala gana, a la idea de que ya no era la única ciudad capaz de hacer algo de sombra a Madrid. Sin embargo, no había perdido ni su orgullo ni su conciencia histórica, y de ello no hay mejor prueba que estas fiestas, empezando por la suntuosa relación que las narra, uno de los libros más lujosos y cuidados que dieron a la luz las prensas españolas del siglo XVII, y que actuó como perpetua memoria de unas celebraciones en las que participaron algunos de los mejores artistas españoles del momento, como Valdés Leal o Murillo. Leyendo este libro o simplemente mirando los magníficos aguafuertes que lo ilustran nos damos cuenta de hasta que punto se aprovechó la relación del Santo Rey con la ciudad que eligió como corte, para convertir a la Catedral en un verdadero espejo donde aparecían reflejados por doquier los monumentos y sectores más característicos de Sevilla. En muchos de los cuadros y esculturas que adornaban los aparatos efímeros se representaba a San Fernando en un entorno sevillano (recibiendo las llaves de la población, en procesión con la Virgen de los Reyes, etc.); y numerosos fueron los jeroglíficos que incluian en su parte gráfica la Giralda, la Torre del Oro, el Guadalquivir o la propia ciudad ${ }^{39}$. Y aunque en todos los casos este tipo de alusiones estaban justificadas por la propia historia del santo y los motivos de la celebración, no podemos dejar de pensar que los sevillanos que entraran en la Catedral se debieron de sentir especialmente complacidos de tener ante sus ojos tantas y tan variadas representaciones de

${ }^{37}$ Véase Moreno Cuadro, F., "Fiestas sevillanas por la canonización de San Andrés Corsino, 1629", Archivo Hispalense, núm. 195 (1982), págs. 111-112. Utiliza la obra de Fray Diego de Angulo, Relación de la solemnísima octava de fiesta, y sermones que en el insigne convento de N.S. del Carmen de ... Sevilla, celebró a la canonización de San Andrés Corsino. Sevilla 1630.

${ }^{38}$ Tanto las fiestas como el libro han dado lugar a una copiosa bibliografía, gran parte de la cual aparece recogida en MORENO CUADRO, F., "Humanismo y arte efimero hispalense: la canonización de San Fernando", Traza y Baza, núm. 9 (1985), págs. 21-98.

${ }^{39}$ Torre Farfan, F. de la, Fiestas de la S.I. Metropolitana y Patriarcal de Sevilla, al nuevo culto del señor rey San Fernando. Sevilla, Vda. de Nicolás Rodríguez, 1671. Por ejemplo, págs. $30,36-37,39-40,41,43,44,52-53,65-66,127$, etc. Vid. Iconografía ..., II, núms. $260-273$. 


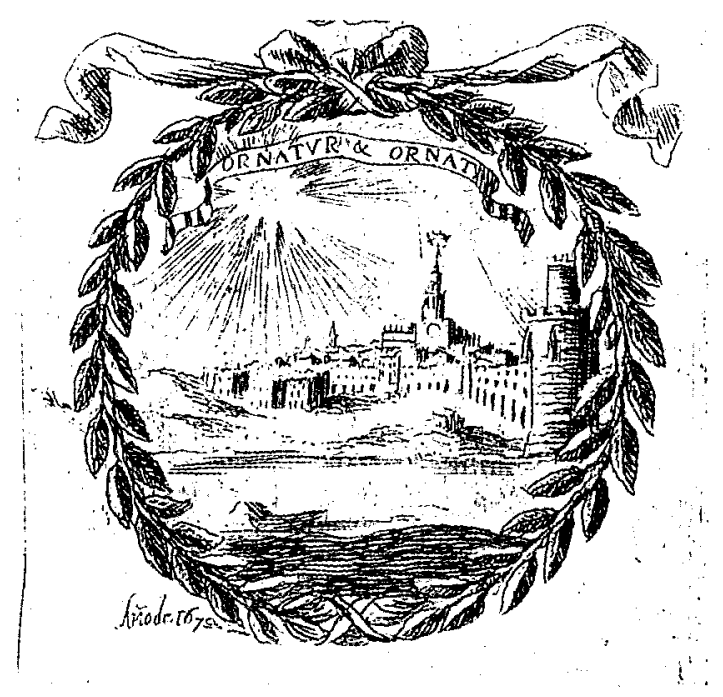

Fig. 11. F. de Arteaga. "Jeroglífico". F. de la Torre Fartán, Fiestas de la S. Iglesia Metropolitana y Patriarcal de Sevilla al nuevo Culto de ... S. Fernando. Sevilla 1671.

una ciudad de la que tan orgullosos se sentían. $Y$ es que durante el Siglo de Oro las fiestas actuaban no sólo para conmemorar un suceso extraordinario, sino también como glorificación de la ciudad, el estado o la institución que las celebraba.

A lo largo de estas páginas hemos tratado de demostrar que los sevillanos expresaron frecuentemente su orgullo local de forma iconográfica. Aunque en el origen de muchas de las representaciones a las que hemos hecho alusión podemos encontrar causas particulares que no tienen en principio por qué ponerse en relación con este orgulio, lo cierto es que el que sean tan frecuentes y variadas las formas en las que se hicieron alusiones gráficas a la ciudad o sus monumentos creemos que no ha de interpretarse como fruto de la casualidad, y que hay que ponerlo en relación con una autocomplacencia del sevillano con su propio entorno. A esta abundancia contribuyó claramente el que hubiera edificios de gran personalidad y fácilmente "transportables" (era, por ejemplo, más fácil hacer acompañar a un santo o cualquier otro personaje de la Giralda, por ejemplo, que de la Alhambra o de la Catedral de Toledo). Y lo que decimos respecto a los monumentos, se puede aplicar también al conjunto de la ciudad, que ofrecía una imagen, como hemos dicho, muy compacta y de gran versatilidad. 